J. Gen. Appl. Microbiol.

Vol. 8. No. 4, 1962.

\title{
THE SIGNIFICANCE OF GLUTAMIC DEHYDROGENASE IN GLUTAMIC ACID FERMENTATION
}

\author{
KAZUO KIMURA \\ From Tokyo Research Laboratory, Kyowa Fermentation Industry Co., Ltd. \\ Received for Publication, August 10, 1962
}

In the previous papers $(1-3)$, it was reported that TPN-linked glutamic dehydrogenase plays a principal role in the biosynthesis of L-glutamic acid in Micrococcus glutamicus.

It has long been known that the pathway of ammonia uptake in microorganisms is either through TPN- or DPN-linked glutamic dehydrogenase $(4,5)$ or through aspartase $(6)$. Recently, the occurrences of L-alanine dehydrogenase $(7,8)$ and L-leucine dehydrogenase $(9)$ were reported, suggesting alternative mechanisms of ammonia uptake. Hong et al. (10) showed that Bacillus having glutamic dehyrogenase lacked alanine dehydrogenase and vice versa. HALPERN et al. (11) reported that the ratio of the activity of glutamic dehydrogenase to that of aspartase in Escherichia coli varied depending upon the compositions of a medium such as nitrogen sources. In order to get further insight into the cause of above-mentioned diversity in the mechanism of ammonia uptake, the activities of various enzymes involved in ammonia uptake were examined with $M$. glutamicus.

The present paper concerns with the recognition of glutamic dehydrogenase as the primary enzyme acting in the process of ammonia upstake $M$. glutamicus irrespective of the cultural conditions so far tested.

\section{EXPERIMENTALS}

Used Strains and Cultivation-Micrococcus glutamicus No. 541, No. 560 (both biotin requiring strains) and several mutants (12) of this species were used. Escherichia coli No. 2 obtained by Kitahara et al. (13) and Bacillus megaterium B-5-5 obtained by Kinoshita et al. (14) were also used. These two strains were known to possess a strong activity of aspartase and excrete a considerable amount of L-aspartic acid in the medium containing fumaric acid. One loopful of the cells grown on a bouillon agar slant for one day at $30^{\circ}$ was transferred to $20 \mathrm{ml}$ of the seed medium in $250 \mathrm{ml}$ flask consisting of $2 \%$ glucose, $1 \%$ peptone, $0.5 \%$ meat extract and $0.25 \%$ $\mathrm{NaCl}$. In the case of the mutants, $0.01 \%$ nutrient required was also included in the medium. The cultivation was conducted with rotary shaking (200 r.p.m.) for 24 hours at $30^{\circ}$. The seed was then transferred, in $10 \%$ inoculum size, to a final medium and it was grown under similar conditions. As the final media were used both the media having the same composition 
as the seed media and the chemically defined media (15) consisting of $10 \%$ glucose, $0.05 \% \mathrm{KH}_{2} \mathrm{PO}_{4}, 0.05 \% \mathrm{~K}_{2} \mathrm{HPO}_{4}, 0.05 \% \mathrm{MgSO}_{4} \cdot 7 \mathrm{H}_{2} \mathrm{O}, 0.002 \% \mathrm{MnSO}_{4} \cdot 4$ $\mathrm{H}_{2} \mathrm{O}, 0.002 \% \mathrm{FeSO}_{4} \cdot 7 \mathrm{H}_{2} \mathrm{O}, 0.2 \%\left(\mathrm{NH}_{4}\right)_{2} \mathrm{SO}_{4}, 0.5 \%$ urea, 0.5 to $20 \mu \mathrm{g} / \mathrm{L}$ of biotin and $0.001 \%$ phenol red. In the chemically defined media, $\mathrm{pH}$ was controlled during fermentation to 7.0 to 8.0 by the addition of urea.

Preparation of Cell-free Extracts-After 24 hours' cultivation, the cells were harvested by centrifugation at $1000 \times \mathrm{g}$ for 15 minutes and washed twice with $0.85 \% \mathrm{NaCl}$ solution. The cells were then suspended in deionized water in the concentration of $100 \mathrm{mg}$ cells per milliliter and disrupted by 10 $\mathrm{KC}$ sonic oscillation for 30 minutes at $0^{\circ}$. The supernatant obtained after the removal of cell-debris by centrifugation at $9000 \times \mathrm{g}$ for 15 minutes was used as the enzyme preparation.

Assay Procedure for Enzyme Activity-The following assay systems were used for the determination of the activities of enzymes in the extracts. In each case, the activity was expressed by the difference between the values obtained for the complete system and the system without the respective substrate.

Aspartase: The complete assay system contained $50 \mu$ moles of $\mathrm{L}$-aspartate, $1 \mu$ mole of $5^{\prime}$-adenylic acid, $100 \mu$ moles of phosphate buffer, and $5 \mathrm{mg}$ of cell-free extract as protein in a final volume of $2.5 \mathrm{ml}(\mathrm{pH} 8.0)$. The activity was expressed by $\mu$ moles of ammonia released during 2 hours of stationary incubation at $30^{\circ}$.

Glutamic-aspartic transaminase: The complete assay system contained $50 \mu$ moles of L-aspartate, $100 \mu$ moles of $\alpha$-ketoglutarate, $20 \mu \mathrm{g}$ of pyridoxal phosphate, $200 \mu$ moles of phosphate buffer, and $4 \mathrm{mg}$ of cell-free extract as protein in a final volume of $2.0 \mathrm{ml}(\mathrm{pH} 8.0)$. The activity was expressed by $\mu$ moles of L-glutamate formed during 1 hour of stationary incubation at $30^{\circ}$.

L-Alanine dehydrogenase: The complete assay system (8) contained 10 $\mu$ moles of L-alanine, $1 \mu$ mole of TPN or DPN, $125 \mu$ moles of 2 -amino-2-methyl1,3 propanediol- $\mathrm{HCl}$ buffer, and $1 \mathrm{mg}$ of cell-free extract as protein in a final volume of $3.0 \mathrm{ml}(\mathrm{pH} \mathrm{9.8)}$. The activity was expressed by the increase in absorbancy at $340 \mathrm{~m} \mu$ during 5 minutes (the increment in optical density at $340 \mathrm{~m} \mu$ between the readings at 15 and 75 seconds after making the last addition was multiplied by 5) per $g$ protein. In the cell-free extracts used a comparatively strong activity of DPNH oxidase was observed. This activity, however, was inhibited $20 \%$ to $40 \%$ by $10^{-2} \mathrm{M}$ cyanide or azide and almost completely by anaerobic condition. Consequently, for the check of DPN-linked dehydrogenases, the reactions were carried out in a THUNBERG tube type cell under anaerobic conditions.

Glutamic-alanine transaminase: Both the assay system and the determination of the enzyme activity were the same as described in the case of glutamic-aspartic transaminase except that L-aspartate was replaced by L-alanine.

L-Leucine dehydrogenase: The complete assay system (9) contained 40 $\mu$ moles of L-leucine, $1 \mu$ mole of TPN or DPN, $150 \mu$ moles of glycine buffer, and $1 \mathrm{mg}$ of cell-free extract as protein in a final volume of $3.0 \mathrm{ml}(\mathrm{pH} \mathrm{11.0)}$. 
The reactions were carried out at $30^{\circ}$ in the same way as described in the case of L-alanine dehydrogenase and the activity was expressed similarly.

L-Glutamic dehydrogenase: The complete assay system (3) contained $50 \mu$ moles of L-glutamate, $1 \mu$ mole of TPN or DPN, $100 \mu$ moles of phosphate buffer, and $1 \mathrm{mg}$ of cell-free extract as protein in a final volume of $3.0 \mathrm{ml}$ $(\mathrm{pH} 7.8)$. The reactions were carried out at $30^{\circ}$ and the activity was expressed in the same way as used for L-alanine dehydrogenase.

Analysis -

L-Aspartic acid: The enzymic reaction was stopped by heating the reaction mixture in boiling water for 5 minutes. After the removal of coagulated protein by centrifugation, L-aspartic acid in the supernatant was determined by the microbioassay using Leuconostoc mesenteroides p 60 (16).

L-Glutamic acid: After the same deproteinization as described above, L-glutamic acid was determined manometrically with the use of L-glutamic decarboxylase of Escherichia coli (17).

Ammonia: The reactions were stopped by the addition of equal volumes of $10 \%$ trichloroacetic acid. After deproteinization by centrifugation, ammonia in the supernatant was determined by the combination of the microdiffusion analysis (18) and the colorimetric assay (19).

Protein: The protein in the extracts was precipitated by the addition of $10 \%$ trichloroacetic acid and redissolved in $1 \mathrm{~N} \mathrm{NaOH}$. The protein contents of the solutions were measured by the Folin-Crocalteu reagent (20) and expressed as the equivalent amounts of egg-white albumin.

Assay of Dehydrogenase Activities: Assays were carried out with Beckman DU spectrophotometer.

\section{RESULTS}

Synthesis of Aspartate from Fumarate and Synthesis of Glutamate from Citrate by the Extracts of Various Species of Bacteria.

To compare the activities of two of the most common systems of the ammonia uptake, one involving aspartase, the other involving glutamic dehydrogenase, the activity to synthesize aspartate from fumarate and the activity to synthesize glutamate from citrate were examined with the extracts of various species of bacteria grown on the glucose bouillon media for 24 hours (in the case of the auxotrophs, with the addition of $0.01 \%$ nutrient required). The results are shown in Table 1. Both E. coli No. 2 and Bacillus megaterium B-5-5 were the bacteria selected specifically for the production of aspartate from fumarate and they were known to possess the strong activity of aspartase $(13,14)$.

Table 1 shows that $M$. glutamicus and its mutants were much weaker in the synthesis of aspartate from fumarate, compared with the other bacteria mentioned above. Therefore, it can be safely said that aspartase does not play any substancial role in the ammonia uptake in $M$. glutamicus. On the contrary, all strains of $M$. glutamicus synthesized glutamate quantitatively 
Table 1. Synthesis of Aspartate from Fumarate and Synthesis of Glutamate from Citrate

\begin{tabular}{|c|c|c|}
\hline Enzyme Source & $\begin{array}{c}(1) \\
\text { L-aspartate } \\
\text { produced } \\
\text { from fumarate }\end{array}$ & $\begin{array}{c}(2) \\
\text { L-glutamate } \\
\text { produced } \\
\text { from citrate }\end{array}$ \\
\hline Escherichia coli No. 2 & ${ }_{9.1}^{\mu \text { moles }}$ & $10.8^{\mu \text { moles }}$ \\
\hline Bacillus megaterium B-5-5 & 9.1 & 0.4 \\
\hline M. glutamicus 560 & 0.0 & 46.5 \\
\hline M. glutamicus 541 & 0.0 & 46.4 \\
\hline M. glutamicus 901 (hom-) & 0.8 & 46.8 \\
\hline M. glutamicus 534-Co 147 (thr-) $^{-}$ & 0.9 & 48.7 \\
\hline M. glutamicus 615-305 (ura-) & 1.0 & 40.0 \\
\hline
\end{tabular}

Reaction mixture:

(1) Fumarate $50 \mu$ moles, $\mathrm{NH}_{4} \mathrm{Cl} 100 \mu$ moles, phosphate $100 \mu$ moles, $\mathrm{Mg}^{++} 2$ $\mu$ moles, cell.free extract $10 \mathrm{mg}$ as protein, $\mathrm{pH} 7.2$, final volume $2.5 \mathrm{ml}$. Stationary, for $3.5 \mathrm{hrs}$, at $30^{\circ} \mathrm{C}$.

(2) Citrate $50 \mu$ moles, $\mathrm{NH}_{4} \mathrm{Cl} 100 \mu$ moles, phosphate $100 \mu$ moles, $\mathrm{Mg}^{++} 2 \mu$ moles, cell-free extract $10 \mathrm{mg}$ as protein, $\mathrm{pH} 7.8$, final volum $2.5 \mathrm{ml}$. Stationary, for $3.5 \mathrm{hrs}$, at $30^{\circ} \mathrm{C}$.

from citrate. The mechanism concerned was previously shown to be the coupling reaction between TPN-linked isocitric dehydrogenase and TPNlinked glutamic dehydrogenase (1). From the comparative studies with the other species of bacteria as shown in Table 1, it became more clear that the ammonia uptake in $M$. glutamicus is carried out by glutamic dehydrogenase and practically not by aspartase.

The results about the auxotrophs shown in Table 1 deserve particular attention. In the order given in the table, these auxotrophs are lysine (21), homoserine (22), and orotic acid (23) producing strains. All of these products are known to be synthesized from aspartic acid $(24,25)$. The fact that aspartate was synthesized from fumarate only in trace amount while glutamate was produced almost quantitatively from citrate by the extracts of these strains indicates that aspartate required for the synthesis of lysine, homoserine, and orotic acid could be supplied by the action of glutamic dehydrogenase and glutamic-aspartic transaminase much faster than by the action of aspartase. Indeed, in all of these extracts, the activity of glutamic-aspartic transaminase was demonstrated to be as strong as that in M. glutamicus No. 541 shown in Table 2 . 
Table 2. Activities of aspartase, glutamic-aspartic transaminase, L-alanine dehydrogenase, glutamic-alanine transaminase, L-leucine dehydrogenase and L-glutamic dehydrogenase of $M$. glutamicus grown on different levels of biotin

\begin{tabular}{|c|c|c|c|c|c|c|c|c|c|c|c|c|}
\hline \multirow{2}{*}{$\begin{array}{c}\text { Biotin } \\
\text { conc. } \\
\text { for } \\
\text { growth } \\
\mu \mathrm{g} / \mathrm{L}\end{array}$} & \multicolumn{2}{|c|}{ Aspartase } & \multicolumn{2}{|c|}{$\begin{array}{l}\text { Glutamic- } \\
\text { aspartic } \\
\text { transamin- } \\
\text { ase }\end{array}$} & \multicolumn{2}{|c|}{$\begin{array}{l}\text { L-alanine } \\
\text { dehydrogen- } \\
\text { ase }\end{array}$} & \multicolumn{2}{|c|}{$\begin{array}{l}\text { Glutamic- } \\
\text { alanine } \\
\text { transamin- } \\
\text { ase }\end{array}$} & \multicolumn{2}{|c|}{$\begin{array}{c}\text { L-leucine } \\
\text { dehydrogen- } \\
\text { ase }\end{array}$} & \multicolumn{2}{|c|}{$\begin{array}{l}\text { L-glutamic } \\
\text { dehydrogen- } \\
\text { ase }\end{array}$} \\
\hline & $\stackrel{+}{\mathrm{AMP}}$ & $\overline{\mathrm{AMP}}$ & $+\mathrm{PP}$ & $-\mathrm{PP}$ & TPN & DPN & $+\mathrm{PP}$ & $-\mathrm{PP}$ & TPN & DPN & TPN & DPN \\
\hline 0.5 & 0.4 & 0.4 & 17.3 & 16.9 & & & 3.9 & 3.6 & & & 105 & \\
\hline 2.5 & 1.1 & 0.0 & 19.0 & 19.0 & 0.0 & & 0.0 & 0.0 & & & 160 & 0.0 \\
\hline 5 & 0.7 & 0.0 & 18.8 & 19.5 & 0.0 & 0.0 & 0.0 & 0.0 & & & 180 & \\
\hline 10 & 1.4 & 0.0 & 16.0 & 14.9 & 0.0 & 0.0 & 0.5 & 2.0 & 0.0 & 0.0 & 123 & \\
\hline 20 & 0.6 & 0.8 & 6.7 & 4.8 & 0.0 & 0.0 & 2.9 & 2.6 & & & 70 & \\
\hline
\end{tabular}

PP: Pyridoxal phosphate

AMP: 5'-Adenylic acid

Used Strain: M. glutamicus 541

Activities of Enzymes Involved in Amnonia Uptake in the Extracts of M. glutamicus Grown on Different Levels of Biotin.

The mechanism of the ammonia uptake in M. glutamicus can be characterized as described above. In the following, the effects of biotin levels in the growth medium upon the mechanism of ammonia uptake were studied in detail. Biotin is an essential growth factor for this microorganism(15) and is shown to exert profound effects upon the metabolic activities of this microorganism $(26,27)$. M. glutamicus No. 541 was grown in the chemically defined media having different levels of biotin and the activities of the enzymes were assayed with the cell-free extracts prepared from the cells grown in these different cultural conditions. The assay systems and the methods of determination of the enzyme activities are described in Experimentals. The results are shown in Table 2 .

The activities of aspartase were shown to be extremely low in all preparations. Only about $1 \mu$ mole of ammonia was released in 2 hours from $50 \mu$ moles of aspartate by the extract having $5 \mathrm{mg}$ protein. Difference in the biotin concentration in the growth media and the addition of the presumed cofactor of aspartase $(28,29), 5^{\prime}$-adenylic acid to the reaction mixture gave only minor changes to the enzyme activities of the cell-free extracts.

The considerably strong activities of glutamic-aspartic transaminase were detected in all preparations. About $20 \mu$ moles of glutamate were produced in 1 hour from $50 \mu$ moles of aspartate by the extract having $4 \mathrm{mg}$ protein. However, difference in the biotin concentration in the growth media gave practically no effect upon the activities of the enzyme. No effect of the addition of pyridoxal phosphate to the reaction mixture was observed, indicating that biotin deficiency did not lower the intracellular 
contents of pyridoxal phosphate to affect the activity of the transaminase.

No activity of alanine dehydrogenase was detected with the addition of either TPN or DPN.

The activity of glutamic-alanine transaminase was detected definitely, although it was weaker than that of glutamic-aspartic transaminase.

No activity of leucine dehydrogenase was detected with the addition of either TPN or DPN.

As previously reported (3), strong activities of TPN-linked glutamic dehydrogenase were observed in all preparations, but the activity of DPNlinked glutamic dehydrogenase was undetectable. Difference in the biotin concentration in the growth media brought about no significant change in the activity of TPN-linked glutamic dehydrogenase.

From the results described above, all of the following three possibilities of the ammonia uptake and consequently of the route of glutamic acid synthesis were practically excluded, i.e. (1) the combination of aspartase and glutamic-aspartic transaminase, (2) the combination of alanine dehydrogenase and glutamic-alanine transaminase, and (3) the combination of leucine dehydrogenase and transaminase.

Therefore, the mechanism of ammonia uptake in $M$. glutamicus can be summarized as follows: TPN-linked glutamic dehydrogenase is the primary enzyme for the uptake of ammonia and L-glutamic acid is produced by the action of this dehydrogenase without preceding formation of other amino acids. The characteristic feature of this mechanism of ammonia uptake does not change with the concentration of biotin in the growth media.

\section{DISCUSSIONS}

The mechanism of ammonia uptake in microorganisms has now been understood to be rather diverse, since the discovery of the dehydrogenases causing reductive amination $(7-9)$ besides DPN-or TPN-linked glutamic dehydrogenase. Furthermore, it was thought to vary not only from species to species (10) but also according to cultural conditions (11).

In view of the recent findings of diversity in the mechanism of ammonia uptake in microorganisms, the extensive re-examination of the activities of enzymes involved in the ammonia uptake was conducted with $M$. glutamicus. The result was the recognition of TPN-linked glutamic dehydrogenase as the principal enzyme for the ammonia uptake in this microorganism. Although the various metabolic activities of $M$. glutamicus were shown to be regulated by the biotin concentration in the growth medium $(26,27)$, no appreciable change was observed in the activities of enzymes involved in the ammonia uptake. Only minor changes were noticed in the activity of aspartase, the general picture of ammonia uptake remaing, however, the same as described above.

The finding that the relative predominance of glutamic dehydrogenase over aspartase remains unchanged in many auxotrophs of $M$. glutamicus 
which produce amino acids or a pyrimidine base of aspartic acid family indicates that this property is inherent to this species of bacteria and quite resistant to mutagenic treatment.

On the basis of the results obtained in the present work, it can be assumed that the alpha-amino groups of aspartic acid and alanine are supplied from that of glutamic acid and, in its consequence, the amino acids belonging to glutamic acid family and aspartic acid family (30) are synthesized directly or indirectly via the synthesis of glutamic acid in M. glutamicus.

\section{SUMMARY}

1. The activity to synthesize aspartic acid from fumaric acid and ammonia and the activity to synthesize glutamic acid from citric acid and ammonia were examined with the cell-free extracts obtained from several strains of $M$. glutamicus and their mutants grown on glucose bouillon media. All of them were found to possess a strong activity of the latter but practically no activity of the former.

2. The activities of aspartase, glutamic dehydrogenase, alanine dehydrogenase, leucine dehyrogenase, glutamic-așpartic transaminase, and glutamic-alanine transaminase were examined with the cell-free extracts obtained from the cells of $M$. glutamicus (parent strain) grown on different levels of biotin. Only glutamic dehydrogenase and transaminases were detected in ample amounts. No significant difference was found in the activities of enzymes involved in the ammonia uptake in the extracts of the cells grown on the different levels of biotin.

3. From the results 1 and 2 , it is concluded that in $M$. glutamicus the principal mechanism of ammonia uptake is effected by TPN-linked glutamic dehydrogenase irrespective of the biotin level in the growth medium, and consequently, the biosynthesis of the amino acids belonging to glutamic acid family and aspartic acid family proceeds directly or indirectly via the synthesis of glutamic acid.

\section{ACKNOWLEDGEMENT}

The author wishes to thank Dr. Shukuo Kinoshita and Dr. Katsunobu TANAKA for their valuable advices throughout this study.

\section{REFERENCES}

(1) Kinoshita, S., Tanaka, K., Udaka, S., and Akita, S.: Proceedings of the International Symposium on Enzyme Chemistry, Tokyo and Kyoto 1957 p. 464.

(2) Kinoshita, S., Tanaka, K., Udaka, S., Akita, S., Saito, T., and Iwasaki, T.: Hakko Kyokai Shi 16, 1 (1958).

(3) Kinoshita, S., Tanaka, K., and Akita, S.: J. Agr. Chem. Soc. Japan 34, 589 (1960).

(4) Euler, H. V., Adler, E., Günther, G., and Das, N. B.: $Z$. physiol. Chem. 254, 61 (1938).

(5) Adler, E., Hellström, V., Günther, G., and Euler, H. V.: Z. physiol. Chem. 
255, 14 (1938).

(6) Quastel, J. H., and Woolf, B.: Biochem. J. 20, 545 (1926).

(7) Wiame, J. M., and Pí́rard, A.: Nature 176, 1073 (1955).

(8) Goldman, D. S.: Biochim. et Biophys. Acta, 34, 527 (1959).

(9) Sanwal, B. D., and ZINk, M. W.: Arch. Biochem. Biophys., 94, 430 (1961).

(10) Hong, M. M., Shen, S. C., and Braunstein, A. E.: Biochim. et Biophys. Acta, 36, 288 (1959).

(11) Halpern, Y. S., and Umberger, H. E.: J. Bacteriol. 80, 285 (1960).

(12) Nakayama, K., Kitada, S., Sato, Z., and Kinoshita, S.: J. Gen. Appl. Microbiol. 741 (1961).

(13) Kitahara, K., Fukui, S., and Misawa, M.: Amino Acids 1, 98 (1959).

(14) Kinoshita, S., NAKayama, K., and KITADA, S.: Hakko Kyokai Shi 16, 517 (1958).

(15) Tanaka, K., IWASAKI, T., and Kinoshita, S.: J. Agr. Chem. Soc. Japan 34, 593 (1960).

(16) Tamura, G., Tsunoda, T., Kirimura, J., and Miyazawa, S.: J. Agr. Chem. Soc. Japan 26, 464 (1952).

(17) Umbreit, W. W., et al.: “Manometric Techniques” p. 207 (1957).

(18) Conway, E. J.: “Microdiffusion Analysis and Volumetric Error" London Crosby Lockwood and Son Ltd. (1950).

(19) Russel, J. A.: J. Biol. Chem. 156457 (1945).

(20) Lowry, O., Rosenbrough, N. J., Farr, A. L., and Randall, R. J.: J. Biol. Chem. 193, 265 (1951).

(21) Nakayama, K., Kitada, S., and Kinoshita, S.: Amino Acids 2, 105 (1960).

(22) Kinoshita, S., Samejima, H., Nara, T., and Fujita, C.: Amino Acids 2, 125 (1960).

(23) TANAKA, K., Nakajima, Y., and Kinoshita, S.: Presented at the annual meeting of Agr. Chem. Soc. Japan in April, 1961.

(24) MeIster, A.: “Biochemistry of the Amino Acids" p. 256 (1957) Academic Press Inc. New York.

(25) ReICHARD, P.: "The Nucleic Acids. Chemistry and Biology" edited by Chargaff, E., and Davidson, J. N. p. 277 (1955) Academic Press Inc. New York.

(26) TANAKA, K., Akita, S., Kimura, K., and Kinoshita, S.: J. Agr. Chem. Soc. Japan 34, 600 (1960).

(27) Kimura, K., Tanaka, K., and Kinoshita, S.: Amino Acids 5, 41 (1962).

(28) Gale, E. F.: Biochem. J. 32, 1583 (1938).

(29) Lieberman, I.: J. Am. Chem. Soc. 78, 251 (1956).

(30) Roberts, R. B., Abelson P. H., Cowie, D. B., Bolton, E. T., and Britten, R. J.: Studies of biosynthesis in Escherichia coli, Publication 607, Carnegie Institution of Washington, Washington, 1955. 